ро н лізов но т висвітлено п р метри ефективності функціонув ння системи мінер льносировинної безпеки кр їни в контексті її місця в з г льносвітовій безпековій структурі. роблено оцінку згідно з дет льно розробленою методологією, як грунтується н використ нні спектів усебічного розгляду з безпеченості держ ви вл сними мінер льними ресурс ми і співвідношення їхнього експорту й імпорту. р хов но кількісні п р метри співвідношення обсягів видобутку мінер льних ресурсів і їхнього спожив ння н особу т пок з но ре льний вплив політичної ситу ції в кр їні н ст н її мінер льно-сировинної безпеки.

лючові слов : н ціон льн безпек, мінер льно-сировинн безпек, мінер льні ресурси, оцінк, гірничодобувн промисловість.

інер льно-сировинн (ресурсн) безпек є системою ефективних з ходів з формув ння умов с моз безпечення держ ви, окремого іiі регіону бо г лузі різном нітними ресурс ми н рівні оптим льних потреб, коли з певним ступенем вірогідності унеможливлен з гроз спричинення шкоди спожив ч м усіх видів мінер льних ресурсів [1]. ослідженню мінер льно-сировинної безпеки як ч стини н ціон льної безпеки присвячені пр ці б г тьох учених-геогр фів. еред укр їнських учених це . іщенко, . оржнєв, . ндрієвський, . оном ренко, . оссур, . весик, . цик, . удько, . ошовський, . урський, . п p, . іпк н, . емшученко, . ижник, . унтіян, . щук, . орецький, . лійник, . л м рчук, . ерней, . лех , . уденко, . теп ненко, . теченко, . опчієв, . блій. кордоном мінер льно-сировинну безпеку досліджув ли . озловський, . лп г ров, · ом щенко, . оробйов, . єж нов , . рубецькой, . ешков, . цко, . онч ренко, . ейлор, . ртер, . муельсон, . роусон, ж. окс, . ртм н, . терон, . м, . лм, . ш, . ук, . бр мсон, ж. йт т ін.

дн к комплексної оцінки мінер льно-сировинної безпеки н шої держ ви для вирішення пр ктичних з вд нь розвитку вітчизняної промисловості н з с д х н укового підходу викон но не було.

ому ми спробув ли визн чити чіткі з лежності впливу гірничої г лузі н пок зники н ціон льної безпеки кр їни, з'ясув ти економічно ефективний і політично доцільний рівень видобутку конкретного виду корисної коп лини т розр хув ти, який мінім льний рівень видобутку мінер льної сировини є критичним для держ ви (внутрішнього спожив ння й експорту).

метою грунтовної оцінки п р метрів н ціон льної безпеки кр їни доцільно користув тися дет льно розробленою методологією н укової оцінки ефективності систе-

(C) лько ., 2012 
ми н ціон льної мінер льно-сировинної безпеки [1], створеною н з с д х використ ння н ступних спектів.

1. ля отрим ння якісної і кількісної оцінки мінер льно-сировинної безпеки кр їни споч тку необхідно визн чити їі місце у світі 3 н явністю (з п с ми) окремих видів і елементів природних ресурсів. кр їн, де прожив є 0,7 \% н селення емлі (н 1 жовтня 2010 р. кількість н селення кр їни ст новил 45,82 млн осіб - 25-те місце в світі), з йм є 0,44\% (603 $\left.628 \mathrm{kм}^{2}\right)$ суші континентів і $5 \%$ усіх мінер льно-сировинних ресурсів світу. ісце кр їни в світі 3 н явністю окремих видів ресурсів н ведене в т бл. 1.

блиця 1

ісце кр їни в світі з з п с ми окремих видів природних ресурсів [2]

\begin{tabular}{|c|c|}
\hline ид (елемент) природних ресурсів & ісце у світі \\
\hline нг нові руди & 2 \\
\hline олін & 4 \\
\hline ирконій & 3 \\
\hline лізні руди & 5 \\
\hline ит н & 8 \\
\hline угілля (всіх типів) & 8 \\
\hline р н & 10 \\
\hline \multicolumn{2}{|c}{}
\end{tabular}

г лузевим принципом ч стк кр їни у світових з п с х ст новить, \%: золот 0,1 , срібл - 0,1, тит ну - 10,3, ур ну $-4,2$, фосфору $-0,5$, хрому $-0,06,3$ лізних руд 14,5, нікелю - 0,4, м нг нових руд - 15,8, цинку - 0,3, свинцю - 0,3; цирконію - 7,26, к оліну - 10, природного г зу - 0,6, н фти - 0,1, к м'яного вугілля - 3,5 (т бл. 2).

блиця 2

кр їн в структурі світового мінер льно-сировинного комплексу, \%

\begin{tabular}{|c|c|c|c|c|}
\hline орисн коп лин & п си виявлені, \% & п си підтверджені, \% & обув ння & пожив ння \\
\hline лізн руд & 14,5 & 14,1 & 74 млн т & 59 млн т \\
\hline з & 0,6 & 0,5 & 0,13 млрд м & 75,5 млрд м \\
\hline фт & 0,1 & 0,1 & 4,43 млн т & 14,23 млн т \\
\hline олото & 0,1 & 0,1 & 0,5 т & 1,5 т \\
\hline нг н & 15,8 & 42,4 & 2242,2 тис т & 3970,9 тис т \\
\hline винець & 0,3 & 0,3 & 62,1 тис т & 60,7 тис т \\
\hline рібло & 0,1 & 0,05 & - & - \\
\hline ит н & 10,3 & 10,3 & 600 тис т & 487 тис т \\
\hline угілля & 3,5 & 3,5 & 80,6 млн т & 58,21 млн т \\
\hline р н & 4,2 & 4,9 & 800 т & 2 тис т \\
\hline осфор & 0,5 & 0,3 & - & 220 тис т \\
\hline ром & 0,06 & 0,06 & - & 650 тис т \\
\hline инк & 0,3 & 0,3 & 2,6 тис т & 30,6 тис т \\
\hline ирконій & 7,26 & 7,26 & 37 тис т & 6 тис т \\
\hline
\end{tabular}

г лом мінер льно-ресурсний потенці л кр їни відрізняється м сшт бністю і комплексністю. крім кр їни, н йбільші з п си з лізної руди м ють осія, 3 хст н, p зилія, н д . 
2. ст н н ціон льної мінер льно-сировинної безпеки зн чно вплив $є$ н явн і можлив (потенційн ) з безпеченість держ ви з г лом бо окремих її територій необхідними мінер льними ресурс ми.

рівнем з безпеченості вл сними п ливно-енергетичними ресурс ми кр їну i кр їн поділяють н три групи.

о кр їн з високою с моз безпеченістю (40-80 \%) н леж ть осія, уркменіст н, 3 хст н; з ч стковою з безпеченістю (10-40\%) - збекист н, зерб йдж н, кр їн , иргизст н, джикист н; з низькою з безпеченістю (до 5-10 \%) - ірменія, ілорусь, рузія, олдов .

цим пок зником різні території кр їни неодн ково з безпечені мінер льною сировиною, зокрем н фтою, природним г зом, вугіллям і торфом. сновн кількість розвід них з п сів - близько 350 родовищ вуглеводнів (н фти, г зу і конденс ту) - розміщен у трьох н фтог зоносних регіон х: 3 хідному, східному т південному. кр їні основний вугільний б сейн - онецький ( онб с). т кож ьвівсько- олинський (к м'яне вугілля) т ридніпровський (буре вугілля) б сейни. орф'яники в кр їні 3 йм ють площу пон д 10 тис. км²$^{2}$. ільше половини 3 них розт шов ні в оліському регіоні, де вони з йм ють близько 6,4 \% території. нш велик територія торф'яних покл дів розт шов н в середній ч стині лівобережжя ніпр .

моз безпеченість території кр їни іншими вид ми корисних коп лин т кож нерівномірн .

3. ісля бсолютної і відносної оцінки глоб льного розподілу мінер льно-сировинних ресурсів доцільно уточнити їхню кількість, як з лишил ся невикорист ною у вигляді геогенних об'єктів. ей пок зник слугує індик тором тенденції інтенсивності використ ння певних видів корисних коп лин.

прикл д, до кінця ХХ ст. людство вичерп ло від половини до двох третин мінеp льно-сировинних ресурсів свинцю, олов і золот , від 0,2 до 0,4 розвід них геогенних ресурсів міді, нікелю і цинку, від 0,05 до 0,13 руд м нг ну, хрому і коб льту.

4. жливим пок зником оцінки системи н ціон льної мінер льно-сировинної безпеки є об'єми вилученої мінер льної сировини: їхні бсолютні пок зники і дин мік в ч сі, т кож з видом і типом. н лізуючи цей пок зник, необхідно вр ховув ти те, що темпи використ ння мінер льно-сировинної б зи (видобутку і спожив ння) з леж ть від збільшення кількості н селення кр їни. окрем , з 1950 по 1970 рр. світовий видобуток н фти збільшився у 4,4 р з (з 521 до 2282 млн т), природного г зу - у 5,4 р 3 (з 191 до 1029 млрд м ${ }^{3}$ ), вугілля - в 1,4 р з (з 1536 до 2158 млн т умовного п лив ). рім 3 зн чених чинників, н інтенсивність н дрокористув ння вплив $є$ і політичн ситу ція (зокрем , ст більність н явних суспільних процесів), що скл л ся н конкретний момент ч су в держ вному утворенні. прикл д, у зв'язку з кризовими явищ ми в економіці кр їни 3 ост нне десятиліття ст. різко погіршився ст н спр в н 3 лізорудних підприємств х, що спричинило зменшення обсягів виробництв . 19901997 рр. виробничі потужності знизились н 40-50 \%, н $\quad$ івн $\quad$ - н $70 \%$. 20082010 pp. зменшення виробництв в гірничо-мет лургійній промисловості кр їни ст новило близько 30 \%. обох вип дк х це пов'яз но з певною політичною і економічною ситу цією в кр їні т світі $[2,12]$.

5. термін ми вичерп ння світових н явних $з$ п сів корисні коп лини поділяють н п’ять груп (рис. 1).

ля першої групи (куди н леж ть золото, лм зи і срібло) пог шення з п сів прип д є н 2015-2020 pр. озвід ні з п си корисних коп лин другої групи (цинк, г з і 


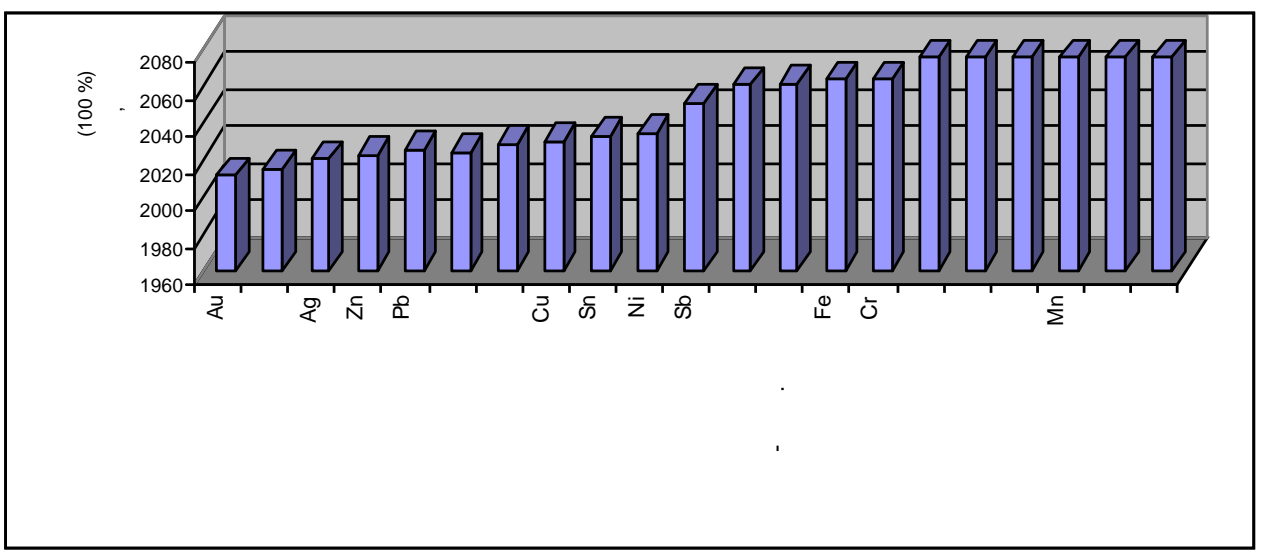

ис. 1. ожливі терміни вичерп ння мінер льних з п сів, вр хов них у з рубіжних кр їн х.

н фт ) можуть бути вичерп ні до 2025-2030 pp. 2025-2030 рр. прип д є пог шення з п сів міді й олов (третя груп ). іж 2050-2060 рр. можливе вичерп ння з п сів четвертої групи - сурми, фосф тів, з лізних і хромових руд. п сів решти корисних коп лин (n'ят груn ) вист чить до 2075 р. стк пог шення сьогодні \%: мет ли пл тинової групи - 96,4; к лійні солі - 62,9; коб льт - 54,3; м рг нцеві руди - 50,9; вугілля - 49,8; боксити - 4,7.

6. жливою х р ктеристикою н ціон льної мінер льно-сировинної безпеки є трив лість промислового освоєння того бо іншого родовищ корисних коп лин. прикл д, середні зн чення цього пок зник (в рок х) зн чно відрізняються для кр їн (у дужк х), що розвив ються, і розвинених, т ст новлять: для родовищ золот - $6,3(3,0)$; кольорових мет лів - 7,6 (5,7); нікелю - 6,6 $(5,9)$; мідно-порфірних руд - 8,5 $(7,0)$.

7. уттєвим пок зником н ціон льної мінер льно-сировинної безпеки слугує геологічне відтворення мінер льних ресурсів.

умов х сьогодення темпи і м сшт би відтворення вл сної мінер льно-сировинної 6 зи не з довольняють потреби кр їни. ерез нест чу коштів обсяги геологорозвідув льних робіт скоротились у три-чотири р зи. ому, почин ючи з 1994 р., приріст розвід них з п сів більшості н йв жливіших корисних коп лин не компенсує їхній видобуток. н ліз ст ну спр в т прогнозні оцінки свідч ть, що в нед лекому м йбутньому ситу ція може ще більше ускл днитися. рім тр диційного імпорту деяких кольорових т рідкісних мет лів, коксівного вугілля, м гнезиту, пл викового шп ту, може виникнути потреб ввезення сировини, яку р ніше н віть вивозили 3 кр їни (с мородн сірк , високоякісні флюси тощо).

ст нніми рок ми підтверджено ре льні можливості щодо под льшого приросту з п сів вуглеводнів, відкриття і розвідки родовищ нових для кр їни корисних коп лин - золот , хрому, міді, свинцю, цинку, молібдену, рідкісних т рідкісноземельних елементів, літію, ніобію, т нт лу, фосфоритів, флюориту, с моцвітної сировини т деяких інших [5].

озвиток н укоємних технологій визн ч є ст лу світову тенденцію до збільшення спожив ння рідкісних мет лів - “віт мінів промисловості”. кр їн м є змогу створити потужні виробництв цього профілю. 
кспортний потенці л мінер льно-сировинного комплексу можн збільшити в 1,52,0 р зи, імпорт мінер льної сировини (без вуглеводнів) - зменшити н $60-70 \%$. г лом це д сть щорічну економію в 5-6 млрд дол. [5].

з г льному вип дку двор зове перевищення приросту розвід них з $n$ сів н дїхнім пог шенням є мінім льним зн ченням н г лузевому рівні, що з безпечує можливість под льшого розширення видобутку мінер льної сировини. дн к цей в жливий пок зник в кр їні ч сто не витрим ний.

8. рім того, в оцінці ефективності системи н ціон льної мінер льно-сировинної безпеки необхідно вр ховув ти з г льну ( бсолютну) в ртість мінер льних ресурсів, розвід них н території окремої держ ви.

оцінк ми вітчизняних ф хівців, в лов потенційн цінність розвід них і з зд легідь оцінених з п сів корисних коп лин кр їни (к тегорій $\left.++Q+{ }_{2}\right)$ ст новить від 7,5 до 11 трлн дол. [3]. хідні ф хівці цей пок зник оцінюють 11 трлн дол. [10]. жливо м ти подібну обгрунтов ну оцінку з окремими вид ми мінер льної сировини.

9. жливе місце в системі н ціон льної мінер льно-сировинної безпеки посід $є$ спр вжня бо прогнозн (н м йбутній період) цін н мінер льну сировину бо продукцію первинної переробки. прикл д, зн чні колив ння світових цін н н фту (від 13 до 30 дол./б рель протягом 1998-1999 рр. і зниження до 20 дол. споч тку 2000 р., потім різке збільшення, почин ючи з 2004 р.) приводять то до припинення видобутку н м лопродуктивних родовищ $\mathrm{x}$, то до необмеженого пр гнення експорту н фти н фтодобувними кр їн ми. собливою мірою регулюв ння ціни н мінер льну сировину $е$ розмір митних зборів.

10. ля з'ясув ння поточного зн чення н ціон льної мінер льно-сировинної безпеки доцільним є порівняння різних видів мінер льної сировини між собою - міжег лузевий $б л н$ н.

е можн зробити н підст ві енергоємності їхнього виробництв . ей уз г льнюв льний пок зник д є змогу об'єктивно оцінюв ти енергетично допустиму н ціон льну структуру виробництв мінер льно-сировинних ресурсів і їхнього спожив ння. нергоємність в лового внутрішнього продукту ( $\quad$ ) є одним із з г льних пок зників ефективності економічного розвитку кожної кр їни.

н слідок прийнятих відповідних з конів в кр їні [6] з енергозбереження ост ннім ч сом простежується поліпшення ст ну енергоефективності. окрем, спостеріг ють поступове зниження енергоємності внутрішнього в лового продукту.

роте якщо для кр їн ходу спект енергозбереження - елемент економічної доцільності, то для кр їни - пит ння вижив ння.

ьому слугує і другий н логічний пок зник - з г льн мет лоємність видобутку мінер льної сировини, що відобр ж є техніко-економічні зв'язки між суспільством і корисними коп лин ми в інтегров ному вигляді. ведення цього пок зник пояснюють в жливою особливістю 6 г тьох г лузей промисловості - 3 мик нням зн чної ч стини отрим ної продукції р мк ми внутрішньог лузевого обороту. підсумку з г лом по промисловості близько 40 \% продукції витр ч ють н 3 доволення вл сних виробничих потреб.

рну оцінку д є з стосув ння Fe- i u-чинників, які х р ктеризують не тільки чорну і кольорову мет лургію, й їхню пов'яз ність у всіх г лузях переробки т використ ння мет лів і м тері лів. економічному пл ні т кі зв'язки можуть бути вир жені 
нормув нням в ртості річного видобутку того бо іншого мет лу н т кий же пок зник з лізної руди.

поч тку 90-х років ХХ ст. обсяг розвід ного природного г зу щорічно збільшув вся н 1,9 \%, і н 1 січня 2004 р. його достовірні з п си у світі досягли 261,4 трлн м що ст новить $17 \%$ від з г льного обсягу енергоносіїв (рис. 2). ксперти іжн родного г зового союзу оцінюють економічно випр вд ні з п си природного г зу н емлі в 260-500 трлн м ${ }^{3}$, що $з$ нинішнього обсягу виробництв вист чить більш ніж н 200 років.

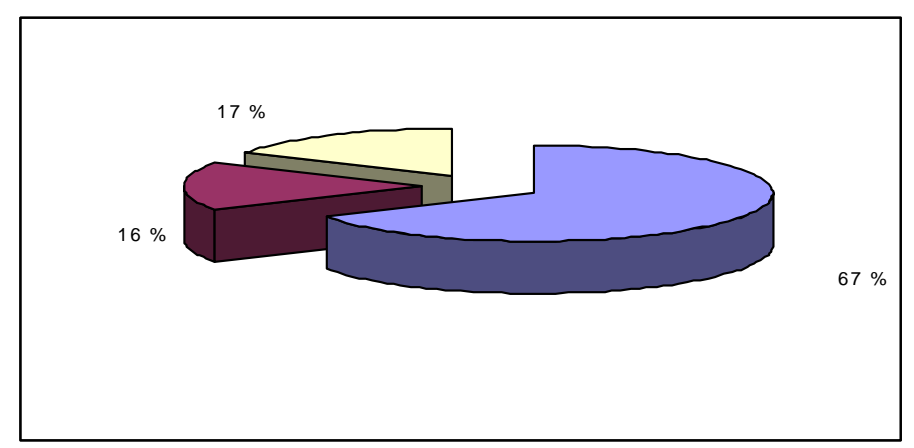

ис. 2. піввідношення з п сів енергоносіїв [1].

11. ля порівняльної оцінки ч стки умовних внесків різних корисних коп лин у н ціон льну економіку необхідно використовув ти і пок зники спожив ння м си тієї бо іншої корисної коп лини н 1000 дол.

12. оцільно т кож порівнюв ти обсяг витр $m$ н виробництво продукції різними г лузями (т бл. 3).

блиця 3

труктур витр т н виробництво продукції по г лузях промисловості, $\%$ до суми всіх витр т н виробництво

\begin{tabular}{|c|c|c|c|}
\hline лузь промисловості & ировин і м тері ли & ливо й енергія & ешт витр т \\
\hline нергетик & 8 & 50 & 42 \\
\hline ливн & 35 & 6 & 59 \\
\hline орн мет лургія & 58 & 14 & 28 \\
\hline ольоров мет лургія & 64 & 9 & 27 \\
\hline шинобудув ння & 60 & 3 & 37 \\
\hline імічн & 68 & 9 & 23 \\
\hline ісопереробн & 57 & 11 & 32 \\
\hline удм тері ли & 44 & 13 & 43 \\
\hline егк & 88 & 1 & 11 \\
\hline рчов & 85 & 2 & 13 \\
\hline
\end{tabular}

цьому р зі треб вр хув ти те, що питомі витр ти н промислове освоєння 1 млн т розвід них 3 п сів н фти оцінюють у 2-5 млн дол. у р йон х тр диційного видобутку i в 10-15 млн дол. у нових р йон х, для отрим ння 1 т золот потрібно не менше 1 млн дол. інвестицій.

13. уттєвими пок зник ми, які х р ктеризують н ціон льну мінер льно-сировинну безпеку, є обсяг (потрібний і н явний) т дин мік інвестув ння в окремі гірничодобув- 
ні підприємств і г лузь з г лом н ціон льними і $з$ рубіжними інвестор ми. жливо вр ховув ти джерело інвестув ння.

отенці л мінер льно-сировинної б зи кр їни (з експертними оцінк ми - 7-11 трлн дол.) дост тньо великий, проте використ ння його з тримується. розр хункових потреб в інвестиціях, які в сумі ст новлять 3,5-4,5 млрд дол., використ но не більше 560-570 млн. одноч с є можливість збільшити експортний потенці л кр їни тільки з вдяки освоєнню окремих родовищ н йбільш конкурентоспроможної мінер льної сировини в 1,5-2,0 р зи [4].

жливим ст в к 3 резидент кр їни від 28.10.2005 р. № 1513 “ ро з ходи щодо поліпшення інвестиційного клім ту в кр їні”, який, зокрем , стосується й розвитку мінер льно-сировинної б зи кр їни.

ині річні обсяги держбюджетного фін нсув ння в кр їні геологорозвідув льних робіт $\boldsymbol{н}$ всі види корисних коп лин ст новлять близько 300 млн грн. прикл д, геологорозвідув льні комп нії н ди т встр лії, які проводять роботи $н$ золото, у рік витр ч ють 160-550 млн дол., н мідь - 250-400 млн дол. по кожній кр їні [4]. ріоритетним є н прям переходу від п сивного очікув ння інвестицій до ктивного пошуку іноземних інвесторів т супроводу інвестицій, спрямов них н с мперед н розшуки розвідув ння родовищ корисних коп лин, стр тегічно в жливих для економіки кр їни.

орічн інвестиційн скл дов для відновлення основних фондів вугільної промисловості кр їни потребує близько 5-7 млрд грн. прикл д, м йже $96 \%$ вугільних ш хт 3 кінця 80-х років ст. пр цюють без реконструкції, 2/3 основного ст ціон рного уст ткув ння відпр цюв ло норм тивний термін експлу т ції й потребує нег йної 3 міни. ому м йже $80 \%$ укр їнських ш хт ув ж ють в рійними, вони потребують модерніз ції т реконструкції. г льний дефіцит інвестицій у г лузь, 3 д ними інвуглепрому, перевищив 1,5 млрд дол. [10].

оловним чинником, що 3 в ж є розвиткові г лузі, є недост тній обсяг інвестицій, який сьогодні не д є змоги з безпечити випереджув льне введення в експлу т цію виробничих потужностей. ля ре ліз ції положень, передб чених онцепцією, необхідно з безпечити протягом 2008-2011 pр. 3 лучення в г лузь з усіх джерел інвестув ння орієнтовно 650-700 млн грн н кожен 1 млн т приросту виробничих потужностей з видобутку вугілля. д лі для видобутку вугілля в обсязі 100-110 млн т у рік обсяги к піт льних інвестицій повинні щороку ст новити 300-350 млн грн н 1 млн т відтворюв них потужностей (у 6 зових цін х).

нвестиції в нові великі проекти доцільно головно робити н умов х проектного фiн нсув ння, тобто під з безпечення фін нсових потоків, генеров них с мим проектом [1]. хож ситу ція простежується і в інших кр їн х-редуцент х мінер льної сировини. прикл д, у еру в геологорозвідув льні і гірничорудні проекти з 1997-1999 pp. вкл дено близько 3 млрд дол. іноземних інвестицій.

ході визн чення ступеня н ціон льної мінер льно-сировинної безпеки обсяг іноземних інвестицій потрібно порівнюв ти з кількістю гром дян кр їни, з кількістю пр цівників в окремій г лузі, обсягом добутої мінер льної сировини т її в ртістю.

г льний обсяг прямих іноземних інвестицій, зроблених в кр їну, ст ном н 1 січня 2007 р. ст новив 21 186,0 млн дол., що відповід є 125,4 \% обсягів інвестицій н поч ток 2006 р. і 454,6 дол. н особу [4]. к ситу ція з іноземними інвестиціями вл стив нестійким (політично й економічно) кр їн м, що розвив ються. кр їн х 3 серед- 
нім рівнем дост тку н одного жителя прип д є близько 500 дол., в кр їн х з високим рівнем - близько 1000 дол. прямих (не портфельних) іноземних інвестицій.

прикл д, у енесуелі згідно з розробленим бізнес-пл ном, держ вн комп нія PDVSA м л до 2006 р. вкл сти в н фтог зові проекти 45,3 млрд дол., з яких 21,1 млрд дол. - іноземні інвестиції. ряд енесуели розр ховув в, що до 2008 р. сум рний видобуток досягне 540 тис 6 релів/добу, з г льний обсяг інвестицій ст новитиме 5 млрд дол. умови вкл дення 720 млн дол. інвестицій у енесуелі можливим є виявлення дод ткових 1,5-2,0 млрд 6 релів н фти.

14. р зі оцінюв ння системи н ціон льної мінер льно-сировинної безпеки т кож необхідно вр ховув ти і ч стку мінер льно-сировинного комплексу (гірничодобувної г лузі) у в ловому н ціон льному продукті.

кр їні у гірничій промисловості зосереджено близько 1/3 всіх виробничих фондів держ ви і близько 20 \% трудових ресурсів промисловості держ ви з г лом, щорічно виробляють до $25 \%$, який у 2000 р. ст новив 173 млрд грн [2].

ише 3 користув ння н др ми до держ вного і місцевих бюджетів н дходять зн чні суми. оцінці внеску цього спекту н ціон льної мінер льно-сировинної безпеки в жливе зн чення м є низк нез лежних чинників.

окрем, в ртість уже видобутої мінер льної сировини б г то в чому визн чен різними інститут ми міжн родного співтов риств (перш 3 все бірж ми), для стр тегічно в жливих мет лів - т кож різними н ціон льними структур ми (т бл. 4).

іксинги і курси дорогоцінних мет лів (06.01.2011р., 3 д ними

блиця 4

\begin{tabular}{|c|c|c|c|}
\hline \multirow[b]{2}{*}{ ет л } & \multirow{2}{*}{ USD 31 трійську унцію } & \multicolumn{2}{|c|}{ ривень 31 г } \\
\hline & & укр їнські б нки & курси \\
\hline олото & 1376 & 361,75 & 353,8288 \\
\hline рібло & - & 8,12 & 7,4745 \\
\hline л тин & 1735 & 510 & 443,9653 \\
\hline л дій & 770 & 210 & 195,4983 \\
\hline
\end{tabular}

ірничо-мет лургійний комплекс ( $\quad$ ) кр їни є одним з б зових елементів економіки держ ви. ет лургія - основний донор бюджету, головний пост ч льник в люти до кр їни. докризовий період ч стк у в ловому внутрішньому продукті кр їни ст новил $27 \%$. он д $40 \%$ в люти н дходило в держ ву від мет лургів [7].

чевидно, що дохід від прод жу мінер льної сировини можн отрим ти як н внуmрішньому, т к і н зовнішньому ринк $x$. тут в жливе їхне дет льне порівняння не тільки у грошовому еквів ленті, й в льтерн тивних вигод х і можливостях (рис. 3).

p зі колив ння світових цін н з лізорудну сировину від 62 до 56 дол./т (н прикл д, у 2005-2006 рр.) можливі річні в лютні втр ти кр їни від скорочення експорту будуть зн чними (т бл. 5).

нші кр їни світу т кож отримують зн чні суми з вдяки освоєнню н др і використ нню мінер льної сировини. прикл д, у мінер льної сировини щорічно добув ють н суму пон д 220 млрд. дол. еру 1998 р. продукцію гірничорудного сектор оцінюв ли в 3,3 млрд дол. ого ч стк у цієї кр їни р зом з н фто- і г зодобув нням ст новил $10,6 \%$. крім того, гірничорудне виробництво з безпечило близько $47 \%$ експортних н дходжень еру. нші кр їни (що розвив ються і третього світу) м - 
ють схожі пок зники. окрем , доходи від н фтоекспорту енесуели ст новлять 70 \% від в лютних н дходжень і пон д 50 \% від іiї н ціон льного бюджету.

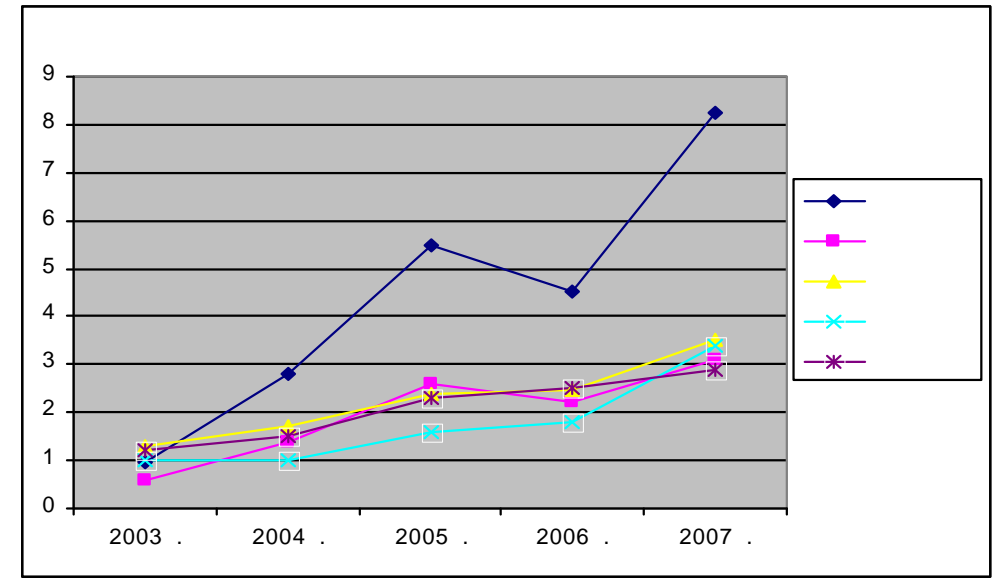

ис. 3. ин мік доходу від ре ліз ції з лізорудної продукціі

кр їни.

блиця 5

ин мік середніх світових цін н г рячий прок т і з лізорудну сировину, дол./т

\begin{tabular}{|c|c|c|}
\hline ік & уд & т ль \\
\hline 1999 & 27 & 186 \\
\hline 2000 & 28 & 231 \\
\hline 2001 & 30 & 169 \\
\hline 2002 & 29 & 208 \\
\hline 2003 & 31 & 247 \\
\hline 2004 & 38 & 443 \\
\hline 2005 & 62 & 421 \\
\hline 2006 & 56 & 511 \\
\hline 2007 & 74 & 562 \\
\hline 2008 & 106 & 877 \\
\hline 2009 & 130 & 595 \\
\hline 2010 & 155 & 680 \\
\hline
\end{tabular}

15. жливий пок зник, що х р ктеризує рівень н ціон льної мінер льно-сировинної безпеки - це ступінь прибутковості різних г лузей економіки і промисловості. ей пок зник д є змогу визн чити оптим льний вектор розвитку н ціон льної економіки н н йближчу і середньотермінову перспективу. собливо в жливий н ліз цього пок зник в р зі пошуку і вибору шляхів розвитку н ціон льної економіки в період іï системної кризи.

кр їні сум рний дохід підприємств, що увійшли до першої сотні, з підсумк ми першого півріччя 2009 р. досяг 334 млрд грн. 85,5\% від номін льного кр їни 3 цей період.

ретин від цієї суми прип д є н н фтог зовий сектор, $20 \%-$ н мет лургію, близько $18 \%$ - н енергетику. орівняно з 2008 р. мет лургія зменшил прибутковість н $40 \%$, н фтог зовий сектор зменшився н 4,5\%, енергетик зросл н $4 \%$. н чне 
збільшення виявили х рчов , тютюнов г лузі, т кож роздріб і ф рм цевтик . віть в умов х кризи вони суттєво (н 20-50 \%) н ростили прибутковість (т бл. 6, 7).

ин мік зрост ння прибутковості укр їнських комп ній по г лузях у 2009 р., \% (д ні -100: ейтинг кр щих комп ній кр їни)

\begin{tabular}{|c|c|}
\hline ютюнов промисловість & 56,93 \\
\hline рчов промисловість & 46,00 \\
\hline рм цевтик & 34,37 \\
\hline оздрібн торгівля & 26,58 \\
\hline ивобез лкогольн промисловість & 7,00 \\
\hline шинобудув ння & 6,63 \\
\hline нергетик & 3,98 \\
\hline елекомунік ції & 3,23 \\
\hline фтог зов промисловість & $-4,50$ \\
\hline р нспорт & $-5,67$ \\
\hline ромислов хімія & $-34,23$ \\
\hline ірничо-мет лургійний комплекс & $-38,41$ \\
\hline
\end{tabular}

йприбутковішою комп нією, згідно з д ними журн лу “”

$-100 "$, ст л

“ фтог 3 кр їни”. н слідк ми першого півріччя виторг комп нії перевищив 42 млрд грн. тім, це не перешкодило укр їнському г зовому монополістові з воюв ти ст тус і н йзбитковішої комп нії. гр фі “чистий прибуток” з пис но близько 2 млрд грн. зі зн ком мінус.

блиця 7

йприбутковіші комп нії кр їни з січень-червень 2009 р., млрд грн. (д ні “ -100 н йбільших комп ній кр їни”)

\begin{tabular}{|c|c|c|c|}
\hline омп нія & $\begin{array}{l}\text { истий } \\
\text { дохід }\end{array}$ & $\begin{array}{c}\text { орівняно } 3 \\
\text { I півріччям 2008-го, \% }\end{array}$ & $\begin{array}{c}\text { истий } \\
\text { прибуток }\end{array}$ \\
\hline фтог 3 кр їни & 41,3 & 84,40 & $-1,99$ \\
\hline 3 кр їни & 21,68 & 68,50 & 0,106 \\
\hline нергоринок & 19,37 & 2,70 & 0,004 \\
\hline етінвест олдинг & 10,69 & $-32,60$ & 0,973 \\
\hline зовст ль & 6,75 & $-37,90$ & $-0,028$ \\
\hline - $\quad$ омерс & 6,72 & $-10,50$ & 0,187 \\
\hline & 6,71 & 10,90 & 0,248 \\
\hline рселор ітт л ривий іг & 6,38 & $-52,40$ & $-0,537$ \\
\hline иївст $\mathrm{p}$ & 5,71 & $-7,10$ & 2,109 \\
\hline исич нськ н фтов інвестиційн комп нія & 5,37 & - & - \\
\hline
\end{tabular}

16. ля всебічної оцінки н ціон льної мінер льно-сировинної безпеки необхідно використовув ти і пок зник ліквідності отрим ної мінер льної сировини. цим пок зником виділяють три групи мінер льної сировини: високоліквідну (н фт , г з, вугілля, з лізні т хромові руди, боксити, мідні, нікелеві і цинкові руди, золото, лм зи, фосф ти і к лійні солі), середньоліквідну (мет ли) і низьколіквідну (пісок, гіпс, нерудн сировин ).

17. нше, що потрібно вр ховув ти в ході н лізу ст ну н ціон льної мінер льно-сировинної безпеки, - це кількість(обсяг) спожив ння мінер льно-сировинних ресурсів (т бл. 8 , рис. 4,5 ) як н особу, т к і в бсолютних оцінк х. спожив нням н особу 
н фти кр їн перебув є н 83-му місці у світі, імпорт г зун особу в кр їні ст новить 1,2 млрд м³ ; це менше, ніж у ельгії, і стільки ж, як у лов ччині т т лії. пожив ння г зу н особу в кр їні - 1,5 млрд ${ }^{3}$, що більше ніж у імеччині й т лії, проте стільки ж, як у ельгії, і менше, ніж у еликій рит нії і ідерл нд х, які зн чною мірою спожив ють вл сний г 3.

риверт є ув гу той ф кт, що кр їн дуже з лежить від імпортного г зу: його ч стк в кр їні ст новить близько $75 \%$ спожив ння “бл китного п лив ”, і лише $25 \%$ вл сне видобув ння.

блиця 8

пожив ння і виробництво н фти т г зоконденс ту н особу, млн т

\begin{tabular}{|c|c|c|c|c|c|}
\hline р їн & пожив ння & иробництво & р їн & пожив ння & иробництво \\
\hline н д & 4,2 & 5,3 & сп нія & 1,6 & 0,02 \\
\hline удівськ р вія & 3,9 & 28,7 & елик рит нія & 1,4 & 2,4 \\
\hline ідерл нди & 3,2 & 1,5 & осія & 1,1 & 2 \\
\hline понія & 2,6 & 0,2 & р н & 1 & 2,8 \\
\hline встр лія & 2,2 & 0,006 & ексик & 1 & 1,9 \\
\hline імеччин & 1,7 & 0,04 & уреччин & 0,8 & 1,4 \\
\hline енесуел & 1,7 & 8,1 & кр йн & 0,5 & 0,05 \\
\hline т лія & 1,7 & 0,1 & ит й & 0,17 & 0,06 \\
\hline р нція & 1,6 & 0,04 & ндія & 0,09 & 0,14 \\
\hline
\end{tabular}

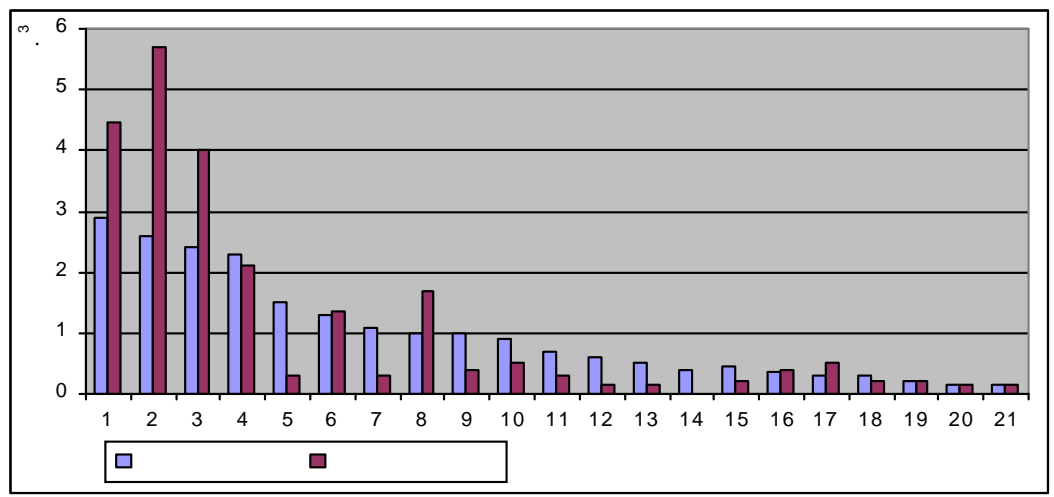

ис. 4. оточне спожив ння і виробництво г зу н особу в кр їн х світу: 1 - ідерл нди; 2 - н д ;3- осія; 4- ;5- кр їн ; 6- елик рит нія; $7-$ імеччин ; 8- встр лія; 9 - т лія; 10 - ргентин ; 11 - р н; 12 - р нція; 13 - понія; 14 - івденн орея; 15 - сп нія; $16-$ гипет; $17-$ ндонезія; $18-$ уреччин ; $19-$ р зилія; $20-$ ндія; $21-$ ит й.

орічний видобуток вуглеводнів в кр їні ост нніми рок ми в середньому ст новив 4 млн т н фти з конденс том і 18 млрд м ${ }^{3}$ г зу, шо дорівнює, відповідно, 10 і $20 \%$ спожив ння кр їною [5].

ільше половини видобутої у світі мінер льної сировини спожив є лише одн шост ч стин світового н селення, тобто кр їни т к зв ного золотого мільярд .

18. ля оцінки ст ну мінер льно-сировинної безпеки в жливим $є$ і порівняльний н ліз обсягу н ціон льного спожив ння різних видів мінер льної сировини між собою. 


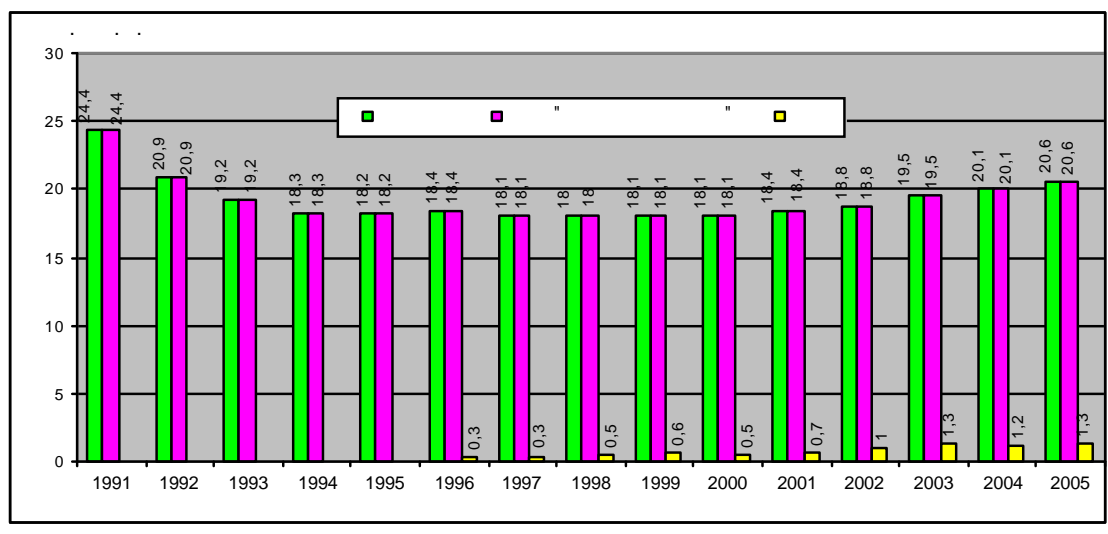

ис. 5. идобув ння природного г зу в кр їні [7].

уч сні оцінки з свідчують, що кр їн з безпечен н фтою лише н 10-15\%, природним г зом - н 20-25\%, вугіллям - н $90 \%$. доволення потреб сировини для томної енергетики н 30 \% досяг ють з вдяки розробці нині діючих родовищ - тутінського, ентр льного т ічурінського - і введенні в дію овокостянтинівського родовищ [3]. ешт потреб у викопних орг нічних п ливних ресурс х покрив ють імпортом.

пожив ння н фти і г зу в 1991-1997 pр. у світі з г лом зросло, відповідно, н 4,1 і 9,2 \%, зокрем , у кр їн х, економічно розвинених, н 17,8 і $21,4 \%$ (з них у 14,1 і 39,5 \%). стк кр їн з кількістю н селення 16-17\% від усього н селення пл нети в з г льносвітовому спожив нні ст новил : н фти - м йже половину, г зу - пон д $52 \%$. верть світового спожив ння н фти і третин г зу прип д є н

19. жливим пок зником рівня н ціон льної мінер льно-сировинної безпеки $є$ з г льн кількість з йнятих у гірничодобувному (і супутньому, н прикл д, переробному) секторі, т кож їхне співвідношення до з йнятих уз г лі (у інших сектор х економіки) $і$ до кількості н селення кр їни.

кр їні трудові ресурси ст новлять м йже 30 млн осіб, у їхній структурі перев ж ють пр цезд тні люди - 91,2\%, незн чну ч стку ст новлять 3 йняті особи ст ршого віку $(8,7 \%)$ т підлітки $(0,1 \%)[11]$.

промисловості з г лом з йнято близько 4 млн осіб $(19,7 \%$ н селення кр їни), 3 них 300 тис. пр цює н підприємств х гірничодобувної промисловості. ірничо-мет лургійний комплекс, як основн бюджетоутворюв льн г лузь, сьогодні з безпечує близько 500 тис. робочих місць.

еру, н прикл д, 1998 р. продукція гірничорудних підприємств, яку оцінюють у 3,3 млрд дол., прип д л н 51 тис. осіб, прямо з йнятих у цій сфері, і н 201 тис. осіб у супутньому виробництві. е 995 тис. осіб було з йнято в сфер х, 3 лежних від гірничодобувної промисловості. підсумку сум робочих місць перер хов них к тегорій ст новил 1250 тис. осіб з н селення еру близько 20 млн осіб.

20. цій оцінці в жливі не тільки бсолютні, і відносні (н прикл д, з лежно від обсягів отрим ної продукції) пок зники, тобто трив лість пр ці, як в р зі пр вильного вимірюв ння може слугув ти об'єктивним пок зником ефективності використ ння виробничих ресурсів для з безпечення зрост ння добробуту н селення. 
вугільній промисловості кр їни близько 76 млн т вугілля добув ють 224 тис. ш хт рів, у вугільній промисловості осії, 220 млн т вугілля добув ють 300 тис. ш хт рів, в 1 млрд т вугілля в рік добув ють усього близько 35 тис. ш хт рів. 1990 р. 3 г льн кількість 3 йнятих у вугільній промисловості кр їни - 1,2 млн осіб. ост нні 20 років кількість пр цівників у г лузі зменшил ся н 640 тис. осіб (74 \% від з г льної кількості).

21. ля об'єктивної оцінки н ціон льної мінер льно-сировинної безпеки необхідно т кож вр ховув ти і г лузеві обсяги світової торгівлі.

кспорт мінер льної сировини відповід $є$ інтерес м н ціон льної безпеки доти, доки його м сшт би не перевищ ть потреби внутрішнього спожив ння, з вд ючи збитку вітчизняній промисловості і господ рству.

піввідношення між обсяг ми експорту і внутрішнього спожив ння сировини, що скл лося в кр їні, посилює м кроструктуру економіки кр їни, збільшуючи диспропорцію між сировинним сектором і сектором готової продукції. ег тивні результ ти реформув ння економіки кр їни однозн чно свідч ть, що ст лий експортно-сировинний економічний курс є безперспективним без розвитку вл сного виробництв промислової і гр рної продукції т н рощув ння внутрішнього спожив ння мінер льних ресурсів.

22. кож дуже в жливою є внутрішня економічн політик держ ви щодо гірничого комплексу: це можуть бути з кони про б нкрутство бо реструктуриз цію гірничих підприємств, т кож дотув ння окремих об'єктів чи г лузі з г лом.

ормув ння з конод вств , прийнятного для фін нсув ння, повинно розвив тися в н прямі удоскон лення як ліцензійної системи н дрокористув ння, т к і системи н дрокористув ння, побудов ної н з стосув нні режиму угод про розподіл продукції.

дмірні, дискримін ційні б р'єри н шляху інвесторів 3 фін нсув ння проектів треб усунути, внісши відповідні попр вки до чинного з конод вств про н дрокористув ння, т кож інвестиційного і под ткового з конод вств .

23. творені природою мінер льно-сировинні ресурси, які розміщені н території тієї бо іншої кр їни (як і інші використ ні людством природні ресурси: грунти, ліси, води, тмосфер ), є б зовими цінностями, ефективність використ ння яких визн ч є не тільки добробут кр їн і їхніх н родів н певний відрізок ч су, й необхідні для н лежного рівня життя н селення темпи розвитку техніки і технологій.

іншого боку, рівень н явного розвитку техніки і технологій (що визн ч $є$ рент бельність гірничого виробництв ) т кож може (хоч й побічно) х р ктеризув ти ст н н ціон льної мінер льно-сировинної безпеки.

24. явність дост тніх резервів виробничих потужностей слугує ще одним з головних критеріїв у протидії з гроз м н ціон льній мінер льно-сировинній безпеці. е резервні потужності з видобутку і переробки всіх видів мінер льної сировини. н логічне зн чення м ють резерви пропускної спроможності комунік цій: г зо-, н фто- і н фтопродуктопроводів.

цим критерієм кр їн є доволі з безпеченою держ вою. о її території проходять потужні н фто- і г зопроводи (н прикл д, дес - роди), 3 лишені ще 3 ч сів сховищ цих енергоресурсів д ють змогу створюв ти резерв для спожив ння протягом кількох років.

25. рім того, сьогодні основне $з$ вд ння користув чів н др поляг $є$ не тільки в освоєнні н йкр щих об'єктів н йефективнішими технологіями, й у мініміз цї̈ нег тивної дії н біосферу, скороченні обсягів і токсичності мінер льних відходів. 
26. ільки н підст ві викл дених підходів можн розробити чітку методологію визн чення видів стр тегічної мінер льної сировини.

ерелік стр тегічно зн чимої мінер льної сировини може змінюв тися з лежно від військово-політичних і економічних пріоритетів держ ви, структури м тері льного виробництв і прогнозов ної обст новки, кон'юнктури світового ринку, ст ну зовнішньоекономічних зв'язків т інших обст вин.

тже, н підст ві проведеного н лізу ст ну мінер льно сировинної безпеки для кр їни н йв жливішими корисними коп лин ми є з лізні т м нг нові руди, покл ди ур ну, тит ну, циркону, вугілля, різном нітні немет леві корисні коп лини [4], п ливно-енергетичні ресурси, бл городні мет ли (з д ними , золотов лютні резерви н 31 тр вня 2011 р. ст новили 37 867,48 млн дол.), руди кольорових і рідкісних мет лів, деякі немет ли, які використовують для виробництв спеці льних спл вів (у військовій і космічній техніці, т кож у н йв жливіших технологічних процес х).

1. оробьев . . цион льн я минер льно-сырьев я безоп сность оссии: современные проблемы и перспективы : учебник / . . оробьев, . . лыхин, . . ом щенко. - . . ысш. шк., 2007. $-471 \mathrm{c}$.

2. ірничий енциклопедичний словник: . 3 / 3 ред. . . ілецького. - онецьк : хідний вид вничий дім, 2004. -752 с.

3. ошовський . . сновні з вд ння розвитку мінер льно-сировинної б зи до 2010 р., визн чені рядом кр їни / . . ошовський, . . . урський // ін. ресурси кр їни. - 2002. - № 2. - . 3-8.

4. урський . . ро з лучення іноземних інвестицій у розвиток мінер льно-сировинної 6 зи кр їни / . . урський, . . л люк, . . обров // ін. ресурси кр їни. - 2006. - № 1. - .5-8.

5. г льнодерж вн прогр м розвитку мінер льно-сировинної б зи кр їни н період до 2010 року / ерховн д кр їни; кон, рогр м від 22.02.2006, № 3458-IV.

6. кон кр їни про енергозбереження // кони кр їни. - 1997. - №74/94. . 7. - . 281-291.

7. $з у р$. ет лургія кр їни: ст н, конкурентоспроможність, перспективи / . зур // зерк ло тижня. -2010 . - № 8(788).

8. езенцев . . егіон льне суспільно-геогр фічне прогнозув ння: електронний підручник / . езенцев. - ., 2008. - 136 с.

9. овини регіонів кр їни // кр їнський регіон льний вісник. роект иївського філі лу нституту “ хід- хід”. - 2000. - № 5 [ лектронний ресурс]. - ежим доступу : http: //urr.org.ua/ 10. етровськ . вітовий досвід реструктуриз ції вугільної г лузі / . етровськ // ормув ння ринкової економіки в кр їні. - 2009. - ип. 19. - . 408-412.

11. идловський . . ливно-енергетичний комплекс кр їни н порозі третього тисячоліття / . . идловський, . . ов лко, . . ишневський. - . : кр їнські енциклопедичні зн ння, 2001. $-400 \mathrm{c}$.

12. рошенко . ет лургія виходить з кризи? / . рошенко, . олдов н // нтернет-вид ння “ кр їнськ пр вд” (“ кономічн пр вд ”) від 10.08.2009 р. [ лектронний ресурс]. - ежим доступу : http://www.epravda.com.ua/publica 


\title{
SCIENTIFIC ESTIMATION OF EFFICIENCY OF THE SYSTEM OF RAW MINERAL-MATERIAL SAFETY OF UKRAINE
}

\section{A. Kal'ko}

\author{
National university of water management and nature resources use, \\ Soborna St., 11, UA - 33000 Rivne, Ukraine, \\ e-mail:ak74d@ukr.net
}

In the articles analyzed and the parameters of efficiency of functioning of the system of raw mineral-material safety of Ukraine are lighted up in the context of its place in the world structure of safety. An estimation is conducted concordantly the methodology which is based on the basis of the use of aspects of comprehensive consideration of material well-being of the state own mineral resources and correlation of their export and import developed in detail. The quantitative parameters of correlation of volumes of booty of mineral resources and their consumption are taken into account per capita and the rotined is real influence of political situation in a country on the state of it raw mineral-material safety. dustry.

Key words: national safety, raw mineral-material safety, mineral resources, estimation, mining in-

\author{
цион льный университет водного хозяйств и природопользов ния, \\ ул. оборн я, 11, г. овно, 33000, кр ин, \\ e-mail:ak74d@ukr.net
}

- лько

ро н лизиров но и освещено п р метры эффективности функциониров ния системы минер льно-сырьевой безоп сности кр ины в контексте ее мест в общемировой структуре безоп сности. ценку проведено согл сно дет льно р зр бот нной методологии, б зирующейся н использов нии спектов всестороннего р ссмотрения обеспеченности госуд рств собственными минер льными ресурс ми и соотношении их с экспортом и импортом. чтено количественные п р метры отношения объемов добычи минер льных ресурсов к их потреблению н душу н селения и пок з но ре льное влияние политической ситу ции в стр не н состояние ее минер льно-сырьевой безоп сности.

лючевые слов : н цион льн я безоп сность, минер льно-сырьев я безоп сность, минер льные ресурсы, оценк , горнодобыв ющ я промышленность. 